\title{
Risk ANd FDI Flows to Developing Countries
}

\author{
Jay van Wyk \\ Department of Management and Marketing, Kelce College of Business, \\ Pittsburg State University \\ Anil K Lal \\ Department of Economics, Finance and Banking, Kelce College of Business, \\ Pittsburg State University
}

\begin{abstract}
The explanatory power of institutional and macroeconomic variables for FDI stock accumulation in developing countries is investigated. Hypotheses are tested by means of pooled least squares regressions. The impact of institutional variables on FDI flows produced mixed results: levels of economic freedom facilitate inward FDI; political risk dampens investment. Some macroeconomic variables displayed significant explanatory power: market size (as measured by per capita income in the base year) and absolute growth of GDP positively impacts FDI inflows. Other key macroeconomic variables, such as lower current account balance, appreciation of host country's currency, and lower inflation rate stimulate FDI inflows.
\end{abstract}

Abstract

Keywords: Institutional theory, macroeconomic theory, foreign direct investment, developing countries, political risk, economic freedom

JEL M19

\section{1}

\section{Introduction}

Foreign direct investment (FDI) flows to developing countries (DCs) dramatically increased from an annual average of $\$ 50.1 \mathrm{bn}$ in 1985-1995 to \$233bn in 2004 (UN: 2000, 2003, 2005). The benefits of FDI inflows in host countries in the developing world have been well documented (Lipsey, 2002; Saggi, 2002; Krugman \& Obstfield, 1994; Tomohare, 2004: 5-16: Ram \& Zhang, 2002: 205-225). In general, the advantages for multinational corporations investing in foreign countries have been explained by theories such as strategic rivalry, stages in the product life-cycle, location-specific advantages, and the shortcomings of other entry modes such as exporting and licensing (Knickerbocker, 1973; Vernon, 1966: 211-226; Dunning, 1988). More specifically, this study continues the ongoing analysis of the factors that drive FDI to DCs.
The dual impact of macroeconomic and institutional factors has emerged as a prominent theoretical framework for analysis of FDI flows to DCs. The macroeconomic approach focuses on why net investment among nations tends to flow in certain patterns. This theory attempts to explain FDI with macroeconomic variables, such as inflation, GDP, employment and exchange rate (Alibar, 1970; Froot \& Stein, 1991:11911217; Grosse \& Trevino, 1996:139-155). A second stream of thought applies institutional theory in strategic management literature to explain FDI flows (Kennedy \& Sandler, 1997; Trevino, 1999; Trevino, Daniels \& Arbelaez, 2002). Institutional theory focuses on the institutional "rules-of-the-game" that shape and bind organisational behavior in society (North, 1990).

Owing to the burden of foreignness, MNEs entering foreign markets adapt their overall strategies to environmental conditions in host countries (Hill, 2006: 261-262). By the same 
token, governments in DCs that compete for a larger share of global FDI flows are in the process of liberalising their institutional environments, i.e. the "rules-of-the-game", to create favourable investment opportunities for MNEs.

Faria and Mauro (2004) found that a variety of factors stimulate foreign investment in developing and emerging markets, inter alia, institutional quality, sound macroeconomics, natural resources, and educational levels. Their findings support the notion that countries with weak institutions rely on crisis-prone forms of financing, thereby increasing the frequency and severity of crises. The importance of institutional quality as a driver of investment and growth is well supported in the literature (Knack \& Keefer, 1995; Mauro, 1995; Wei, 2000). Rumelt, Schendel and Teece (1991) provided the intellectual impetus to marry the macroeconomic and strategic management theories in an effort to explain FDI flows. This was taken further by Trevino and Mixon (2004), who utilised strategic factors to explain FDI decisions in Latin America; and Grosse and Trevino (2005), who presented New Institutional Economics (NIE) to explain FDI and location decisions in Central and Eastern Europe $(\mathrm{CEE})^{1}$. A central focus of these studies is that FDI decisions are influenced by a firm's ability to reduce high transactional costs in uncertain investment environments (Hoskisson, Lau \& Wright, 2000). In DCs, additions to transaction costs are brought on by opaque regulatory behaviour, as well as by resource-poor and inefficient judicial and financial systems. The inadequate functioning of institutions in the Middle East and North Africa, in, for example, high political risk, poor governance, corruption, lack of government effectiveness and rule-oflaw failures, preclude these countries from participating fully in the world economy and from attracting more FDI inflows (Moen, 2004:1475-1488).

Empirical research on FDI using the institutional approach has mostly emphasised the impact of incremental risk, e.g. political risk (Bailey \& Chung, 1995), bilateral investment treaties (Heinrich \& Konan, 2001), corruption (Jain, 2001), trade regulations, capital market liberalisation and the rule-of-law (Trevino \& Mixon, 2004). In this analysis, a broader approach is added to the narrower approach to institutions. The focus is on institutional change, both episodic and incremental (Cortell \& Peterson, 2002: 2-5). Episodic changes involve degree of change, i.e. reform or restructuring of institutions, and scope of change, i.e. institutional innovations that impact economic, political and social systems.

According to Keeler (1993: 433-386), dramatic events open windows of opportunity for institutional change. Events like the end of the Cold War and developments like globalisation have led to broad institutional changes in political economies, including market and economic liberation and democratisation. The first reduced barriers to international trade and investment; the latter created a business environment attractive to FDI inflows owing to higher levels of transparency, continuity and predictability. If episodic changes address opportunity, then incremental changes, or even the lack thereof, refer to threats or risk. Slow changes to political instability (macro-political risk) and intrusive market regulation (micropolitical risk) remain at the heart of the risk profiles of host countries (Howell \& Chaddick, 1994: 70-91; Root, 1972: 345-365; Fatehi \& Safizadeh, 1994: 65-73; Kobrin, 1976: 29-42). Such institutional arrangements, i.e. higher levels of transparency, continuity and predictability, produce conditions favourable to attracting FDI. In contrast, DCs are characterised by less structural-functional differentiation between political and economic institutions, which inhibits both economic opportunity and political choice (Huntington, 1971: 283-322). This study will argue, therefore, that improved levels of political-economic freedom may be seen as an important institutional change that will facilitate lower costs and higher FDI inflows in DCs.

The rationale for this paper is threefold: first, the analytical focus will be on developing countries. Following Bloniger and Wang (2004), we argue that the practice advocated in many empirical studies of FDI of pooling developed economies together with developing markets is inappropriate. Developed economies have substantial amounts of two-way FDI flows, 
whereas developing countries are almost exclusively recipients of FDI flows. Second, in the International business literature, the influence of New Institutional Economies on FDI flows to developing countries has been limited to smaller regional samples, such as Latin America, Central Europe and East Asia (Trevino \& Mixon, 2004; Crosse \& Trevino, 2005; Zhan, 2001). This study includes a sample of 31 developing countries from all the major regions in the world economy. Third, understanding of institutional quality is still a work-in-progress. This study introduces the institutional variables such as economic freedom as a proxy for market capitalism, and political freedom, as a proxy for democratic government. This paper is set out in five parts: (1) literature overview of institutional variables that may influence FDI decisions; (2) literature review for macroeconomic variables; (3) data and methodology; (4) discussion of findings in relationship to postulated hypotheses and its attendant NIE theoretical discourse; (5) discussion of managerial implications of the findings and a brief conclusion.

\section{2 \\ Literature review of institutional variables}

From the perspective of international business, two institutional developments have particularly stimulated FDI flows to developing countries. The liberalisation of trade and the spread of the free market philosophy have created business opportunities, which in turn have led to firm activities like acquisitions, mergers, and green field investment in these markets. The spread of representative and accountable political governance in developing countries has lowered instability and strengthened investment confidence in the emergence of more transparent business environments. However, these two liberalisation trends are fraught with setbacks, and there is only partial progress in the creation of workable political and economic institutions. As much as institution building and sound macroeconomics create opportunity, and "pull" investments to developing countries, investors are still exposed to a range of risks.
This may inhibit investment considerations like the absence of factors of production, or, when it comes to existing investments, may expose a firm to a decline in profitability and loss of assets (Hill, 2008; Cavusgil, Knight \& Riesenberger, 2008).

\section{3}

\section{Political risk}

For foreign investors, the primary concern about political risk (PR) in host countries is the adverse impact it may have on a firm's profitability. Such adverse events originate in governmental discriminatory and regulatory policies, the expropriation of assets, and events emanating from the political system of the host country that may disrupt business operations, damage assets or endanger employees (Butler \& Joaquin, 1998) $)^{2}$.

On balance, the literature indicates that PR is an impediment to FDI and that MNEs are more likely to avoid host countries with a high PR profile (Erramilli \& Rao, 1993) and higher transaction costs (Nigh, 1985; Schollhammer \& Nigh, 1984). Grosse and Trevino (1996) and Bailey and Chung (1995) attribute this to the inability of host countries to reduce PR as well as their failure to alleviate investors' uncertainty about unanticipated costs and reduced ROI associated with long-term capital investments. Smith-Hillman and Omar (2005) identified that proportionally smaller FDI inflows occurred to less developed economies in comparison with developed economies. This was the response of MNEs to weak governance, high PR and a regional predisposition to corrupt practices. From a regional perspective, Trevino and Mixon (2004) found that PR was a significant inhibitor of FDI flows to Latin America. Grosse and Trevino (2005) found an inverse and significant relationship between PR and FDI flows in Central and Eastern Europe.

Zhoa (2003) found an inverse relationship between PR and FDI inflows to China, the most prominent host country for FDI among DCs. The major concern of source countries was that political uncertainties in China may worsen their operating positions and inhibit profit expectations. A contrary view is that high risk in 
DC host countries is not an impediment to FDI inflows. According to Albuquerque (2000), the share of FDI in total inflows is higher in more risky countries as a measure of country risk or credit ratings for sovereign debt. Razin (2003: 415-428) argued that direct investment in more risky countries provides firms with direct control over operations rather than relying on indirect control, e.g. licensing or exports. Pan (2003) and Pan and $\mathrm{Li}$ (2000) show that FDI inflows into China, despite the country's high political risk profile, is driven by long-term strategic advantage rather than short-term risk exposure. Acquiring higher levels of equity and gaining control of joint ventures in the politically risky Chinese environment may be overshadowed by current positioning to strengthen competitive advantage for the long run. A study by Pan (2003) found contradictory results: a more favourable risk assessment of China was associated with smaller FDI flows. However, Pan utilised country risk data which is a more diffused and broader aggregate than PR.

Hypothesis 1: There is an inverse relationship between political risk in DCs and the stock of FDI in such countries.

\section{4}

\section{Operations risk}

Companies investing in DCs face a range of operations risks (OR). OR is common in countries that have no clear, accurate, easilydiscernible and widely-accepted practices governing the relationships among firms, investors, governments and courts. This refers to micro political risk, i.e. government policies aimed at market restriction (Balasubramanyam \& Mahambare, 2002). According to Kurtzman, Yago and Phumiwasana ( 2004), OR is largely informed by opacity, i.e. insidious and incremental small-scale risks like fraudulent transactions, bribery, legal and regulatory inefficiencies, unenforceable contracts and negative attitudes towards foreign investors, rather than dramatic risk events (macro political risk) like revolutions, major acts of terrorism, and expropriation of private property. OR interferes with commerce, adds costs, slows growth and hampers prediction about the future. It influences FDI decisions on where to develop markets, locate production facilities or find suitable outsource partners. Kurtzman, Yago and Phumiwasana (2004) found, based on an Opacity Index, that for every one point increase in their opacity index, FDI as a percent of GDP decreased by one percent. ${ }^{3}$ They also identified an interest rate premium or discount derived from doing business in host countries as opposed to doing business in the USA. All DCs surveyed had an opacity premium, i.e. India 6.09 per cent, China 6.49 per cent and Indonesia 8.54 per cent.

There is no lack of literature studies to support the above arguments. Miklos (1995) identified the deficient flows of information, bureaucratic inefficiencies and opaque privatisation practices as inhibitors of FDI flows to Hungary. Blackman and $\mathrm{Wu}(1999)$ found that there are numerous institutional barriers to FDI in the Chinese power sector, such as uncertainty associated with the approval process for FDI projects, complex regulations, and the risk of default on power purchase contracts.

Various studies have established that different elements of broad OR have a negative bearing on FDI flows to DCs. These elements include disjointed privatisation of state-owned enterprises (Carstensen \& Toubal, 2004; Perotti \& Van Oijen, 2001; Sader, 1993), corruption (Voyer \& Beamish, 2004; Jain, 2001), capital control policies (Asiedu \& Lien, 2004) and expropriation (Burton \& Hisashi, 1987).

Hypothesis 2: The higher the operations risk in DCs, the lower the FDI inflows to such countries.

\section{5}

\section{Political and economic freedom}

In a study of North African and Middle Eastern countries in the 1990s, Moen (2004) concluded that political economic liberalisation, i.e. improvement in the quality of institutions, may result in an increase in FDI inflows and manufactured exports. Ahmed (2003), in a study of five South Asian countries, reached the same conclusion: an increase in political rights and democracy has led to an increase in FDI 
inflows. Globalisation (i.e. FDI), in its turn, is likely to promote democratic governance. The pace of political-economic reform is another critical factor in attracting FDI inflows. In a study of more than 1000 policy changes in DCs, Kobrin (2005) found that 95 per cent of DCs either lessened restrictions on inflows of FDI or provided additional promotions and incentives to attract increased inflows. For host countries, institutional liberalisation is a rational process to avoid the "cost of closure" and to improve national competitive advantage. Accommodating demands for liberalisation emanating from major industrialised countries and international financial institutions are major drivers for FDI inflows in DCS ${ }^{4}$.

Asiedu (2004) found that Sub-Saharan African countries have reformed their institutions, improved infrastructure and liberalised FDI regulations. However, the pace of reform in Sub-Saharan Africa has been very average in comparison with the reforms implemented in other DCs. As consequence, Sub-Saharan Africa, relative to other regions, has become the least attractive host for FDI inflows, attracting only a 1.2 per cent share of global FDI (UN, 1999). An analysis of Bulgaria showed that low FDI inflows were functions of political unwillingness to make significant reforms (e.g. delays in privatisation) and of the inefficiencies of the post-communist Bulgarian government (Bitzenis, 2004).

In an empirical study of 80 countries from 1980-1998, Jensen (2003) found that democratic countries are predicted to attract as much as 70 per cent more FDI than their authoritarian counterparts. Li and Resnick (2003) argued that democratic governments in DCs can both promote and jeopardise FDI inflows. Democratic institutions hinder FDI inflows, e.g. limiting the oligopolistic or monopolistic actions of MNEs, protecting local producers against foreign competition, and constraining the ability of host governments to offer discretionary financial and fiscal incentives to foreign investors. On the other hand, democratic institutions promote FDI inflows because they tend to guarantee more credible property rights protection, and to reduce risks and transactions costs for foreign investors. Hence, the net effect of democracy on FDI inflows is contingent on the relative strength of these two competing forces.

Hypothesis 3: There is a positive correlation between the level of political/economic freedom in DCs and the volume of FDI inflows.

\section{6 \\ Literature review of macroeconomic variables}

\subsection{Market size}

Conventional wisdom dictates that the demandside of FDI drives investments in developed countries rather than in DCs (Grosse \& Trevino, 1996). A number of studies now show that market size is also a strong incentive for FDI flows to DCs. The UN (1998) found, in separate analyses during three five-year periods from 1980 to 1995 across all emerging markets, that nominal GDP was a strong positive factor in explaining FDI flows into these countries. Zhao (2003) found that GDP growth is a strong driver of FDI inflows into China. If Hong Kong is excluded from the regression model, the significance of GDP growth increases ${ }^{5}$.

Basu, Chakraborty and Reagle (2003:510516) found a bidirectional causality between GDP and FDI in open economies and a unidirectional causality between GDP and FDI in closed economies in DCs. Tahir and Larimo (2004) found that large market size particularly stimulates market-seeking and efficiency-seeking FDI in the emerging markets of South and Southeast Asia. In an analysis of FDI inflows to Latin America, Trevino, Daniels and Arbelaez (2002) established that GDP was a strong indicator of FDI inflows.

Hypothesis 4: The larger the market size, as indicated by per capita GDP, of host countries in the developing world, the greater the flow of inward FDI.

\subsection{Economic growth}

In the literature, the causality that runs from GDP growth to FDI is well supported. Such a growth-driven hypothesis has been supported by the findings of Chowdhury and Mavrotas (2003), 
Gyapang and Karikam (1999), Merlevede (2000), Wheeler and Mody (1993) and Zhang (1995). According to Hsiao and Shen (2003), China illustrated that a 1 percent increase in GDP led to a 2.117 percent increase in FDI in the short run and a 34 per cent increase in FDI in the long run. Rapid economic growth enhances the confidence of overseas investors to engage in FDI (Zhang, 1999; Zhang, 2001). More importantly, such economic growth creates enormous opportunities to invest in recipient countries' industrial sectors, consumer durable goods and infrastructure sectors (Shan et al., 1997; Shan 2002). The literature also supports a bi-directional causal relationship between economic growth and FDI. Tomohara (2004) found that FDI by MNEs, rather than protecting infant domestic companies, yields a larger market, thereby fostering economic growth.

Hypothesis 5: The higher the economic growth rate of host countries in the developing world, the greater the inward flow of FDI.

\subsection{Inflation}

In many parts of the developing world characterised by fragile democracies and markets, there is macroeconomic instability. Risks include instability of prices, interest rates, exchange rates, and economic output, as well as unemployment. Inflation is caused by excessive growth in the money supply. In countries moving from a command or state-controlled economy to a market economy, inflation is often submerged owing to price fixing and market deficiencies. A host country's inability to maintain a consistent monetary policy may lead to high inflation and internal economic instability. MNEs faced with an institutional environment of high inflation will in all likelihood experience uncertainty in the capital budgeting and long-term planning. As a result, the capital commitments of MNEs are exposed to higher risks and increased uncertainty and costs.

From the MNEs' point of view, high inflation creates uncertainty as to the realised net present value of a costly long-term capital investment. These conditions may also inhibit export sales from the host country, thus rendering resourceseeking FDI less attractive. The literature tends to support the argument that high inflation or hyperinflation in DCs inhibits FDI inflows ${ }^{6}$.

According to Tahir and Larimo (2004), Finnish companies seeking risk reduction FDI in Asia were strongly informed by low levels of inflation and low levels of political risk. Studies published before Latin American countries embarked on market liberalisation and those published after reforms were enacted confirmed that companies invested less in DCs with high inflation rates (Schneider \& Frey, 1985). Grosse and Trevino (2005) found that inflation did not add significantly to the explanation of FDI flows into the CEE countries. Companies have possibly gained much operating experience in high-inflation environments around the world and may no longer perceive high inflation as so problematic as to justify their keeping out of potentially attractive and profitable markets.

Hypothesis 6: There is an inverse relationship between inflation and FDI inflows: the higher the inflation rate in a developing country, the lower the level of FDI inflows.

\subsection{Currency valuation}

Currency valuation may impact an MNE's decision to invest in DCs in various ways. The absence of a stable, well-accepted currency in a host country may lead to unanticipated depreciation and volatility in a host country's exchange rate. This introduces uncertainty in long-term planning and exposes long-term investment to increased risk. The causes of currency devaluation and volatility may result from the failure of macroeconomic policy and political instability, both being difficult to predict. Host countries with persistent currency volatility may thus be avoided in favour of countries whose currencies are expected to maintain the value of their earnings on such investments. Erdal and Tatoglu (2002) found, in a study of locational factors on the level of FDI flows to Turkey, that the lack of exchange rate stability hindered Turkey's efforts to attract a much higher volume of FDI.

Esuola and Adeleke (2006: 219-224) found that exchange rate is the strongest macroeconomic driver of FDI inflows in Nigeria. MNEs from source countries with a strong currency (over- 
valued) would tend to invest more in economies with a relatively weak currency (under-valued). Exchange rate fluctuations affect FDI in this regard in two ways: (1) the appreciation of a source country's currency vis-à-vis a host country means that the source country's investment increases in value when denominated in the host country's currency (Ajami \& Barniv, 1984; Dewenter, 1995); and (2) currency appreciation increases a firm's wealth position, lowers its relative cost of capital and allows it to invest more aggressively overseas (Froot \& Stein, 1991).

Hypothesis 7A: The greater the depreciation of the host country's currency, the higher the host country's inward FDI.

Hypothesis7B: The greater the depreciation of the host country's currency, the lower the host country's inward FDI.

\subsection{Balance of payment}

The impact of FDI on DCs' balance of payment (BOP) is an important policy issue for most host governments ${ }^{7}$. For many DCs, attracting FDI from foreign MNEs has been a major driver of export-led economic growth (UN, 2002). The benefits of FDI inflows, as outlined above, are many, but their adverse effects on the current account are a cause for concern for host countries. Despite the initial capital inflow that comes with FDI, a subsequent outflow of earnings from the foreign subsidiary towards its parent company will also occur. Such an outflow will show as capital outflows on the BOP account. A further concern arises when a foreign subsidiary imports a substantial number of inputs from abroad that will be recorded as a debit on the current account of the host country's BOPs. Large developed countries, such as the USA, may tolerate a persistent current account deficit by financing it through the sale of assets like stocks, bonds, real estate or companies (Krugman \& Obstfield, 1994). However, governments in DCs often adopt a nationalistic stance and disapprove of national assets falling into foreign hands, preferring their nation to maintain a current account surplus. This goal may be achieved in two ways. First, FDI is perceived as a substitute for imports of goods and services that, in turn, may improve the current account of the host country's BOPs. MNEs that use foreign subsidiaries to export goods and services from the host country to other countries will also strengthen the surplus of the host country's current account. Second, governments in DCs may also restrict the repatriation of profits from a subsidiary to a parent company in an effort to limit debits on the current account (Hill, 2006). Alternatively, host countries may conserve their foreign exchange reserves when MNEs reinvest their earnings. Reinvesting in local manufacturing facilities may also improve the competitiveness of local producers and boost a host nation's exports, thereby improving its BOP position (Wild, Wild \& Han, 2006).

From a political science perspective, the link between the election cycle and the business cycle may create BOP problems. According to Nordhaus (1975) and Tufte (1978), a government facing re-election may reduce unemployment through expansionary monetary or fiscal policy prior to the election, albeit at the cost of increasing inflation in the post-election period. In a study of Latin American countries, Schamis and Way (2003) found that during the election cycle governments repeatedly chose policies that stimulated boom-bust business cycles which, in turn, were the main causes of financial crises related to BOP and exchange rates. The political rationale of exchange-based stabilisation, from the standpoint of opportunist office-seeking governments, explains its persistent popularity despite its questionable attractiveness as an economic policy.

Hypothesis 8: A deficit on the current account of the BOP of a host country will be inversely associated with FDI inflows in DCs; and a surplus on the current account of the BOP of a host country will be positively associated with FDI inflows in DCs.

\section{7}

\section{Data and methods}

The dynamic nature of FDI activities lends itself to time-series analysis as a robust way of capturing trends in MNE investment choices. 
To capture a sufficient number of observations, a comparative cross-country time-series dataset was assembled using $31 \mathrm{DCs}$ covering the period 1995-2003. The panel of 31 countries includes Argentina, Brazil, Chile, China, Colombia, the Czech Republic, Ecuador, Egypt, Hungary, India, Indonesia, Iran, Israel, Malaysia, Mexico, Morocco, Nigeria, Pakistan, Peru, Philippines, Poland, Russia, Saudi-Arabia, Singapore, South Africa, South Korea, Thailand, Turkey, Ukraine, Venezuela and Vietnam. Other studies that investigate the influence of New Institutional Economics, macroeconomics and institutions on FDI, mainly have a regional focus, for example, Latin America (Trevino \& Mixon, 2004) or Central and Eastern Europe (Grosse $\&$ Trevino, 2005). In this sample, states from all the developing regions have been included in an effort to obtain a more comparative analysis of investment issues.

To examine the causes of Foreign Direct Investment (FDI), we postulate the following:

FDI $=f($ Market size, Rate of Growth of GDP, Inflation Rate, Current Account Balance, Exchange Rate, Political Risk, Operational Risk, Economic Freedom)

Based on our initial estimation results, we decided to use the log-linear functional form to estimate the causes of FDI. Since logs cannot be used in the case of negative numbers, we modified our original data to enable the use of logs.

FDI: Inward FDI stock (millions of US\$) ${ }^{8}$

Market size: 1995 GDP (2000 US\$) or 1995 per capita GDP (2000 US\$): G95 or PCG95.

Rate of Growth of GDP: GDP (2000 US\$): GDP

Inflation Rate: CPI $(2000=100)$ : CPI

Current Account Balance: Export of Goods and Services (current US\$)/Imports of Goods and Services (current US\$): CB

Exchange rate: Local currency per US\$: ExR Political Risk: PRISK

Operational Risk: OPRISK

Economic Freedom: EF
Specifically,

$\log (\mathrm{FDI})=$ constant $+\operatorname{alog}(\mathrm{G} 95$ or PCG95) $+b \log (\mathrm{GDP})+\operatorname{clog}(\mathrm{CPI})+\mathrm{d} \log (\mathrm{CB})+$ $\operatorname{elog}($ ExR $)+$ flog(PRISK $)+\operatorname{glog}($ OPRISK $)+$ flog(EF) + error term

The advantage of using log formulation is that it enables easy interpretation of the data as coefficients associated with independent variables or parameter estimates measure respective elasticities. For example, 'c' indicates that inward FDI stock changes by ' $c$ ' percent when prices change by 1 per cent (or 1 per cent inflation rate causes 'c' percent change)

\section{8}

\section{Results}

As stated in the introduction, the objective of this analysis is to examine whether the level of FDI inflows into a panel of DCs may be attributed to institutional and macroeconomic variables. To determine the presence of multicollinearity, a Pearson correlation was run with the independent variables.

As outlined in Table 1, two independent variables are indeed strongly correlated. PRISK is strongly correlated with another institutional variable, OPRISK. OPRISK was therefore omitted from our analysis. We also found a positive correlation between ExR and CPI. Hence, we have one or the other in our estimation.

The data for FDI was obtained from World Investment Report 2005 (UNCTAD). The data for G95, PCG95, GDP, CPI, CB, and ExR was obtained from World Development Indicators 2006 (the World Bank). For PR we used two different data sources. Freedom House ranks countries based on political rights (PR), which are measured on a scale of one to seven, with one presenting the highest degree of political freedom, and seven the lowest. Political risk (PRISK) is measured by Business Environment Risk Intelligence. The index measures on a scale of $0-100$, the higher the aggregate score the lower the country's political risk. For EF, we used the Index of Economic Freedom compiled by the Wall Street Journal and the Heritage Foundation (the index measures on a scale of $0-100$, higher score indicating higher economic freedom $)^{9}$. 


\section{Table 1}

Correlation matrix

\begin{tabular}{|c|c|c|c|c|c|c|c|c|c|}
\hline & FDI & PRISK & OPRISK & GDP & EXR & $\mathrm{CPI}$ & $\mathrm{CB}$ & PCG95 & EF \\
\hline FDI & 1.000000 & & & & & & & & \\
\hline PRISK & -0.158576 & 1.000000 & & & & & & & \\
\hline OPRISK & -0.094801 & 0.728377 & 1.000000 & & & & & & \\
\hline GDP & 0.656020 & -0.198123 & -0.003157 & 1.000000 & & & & & \\
\hline EXR & -0.040613 & -0.073958 & -0.007237 & 0.000161 & 1.000000 & & & & \\
\hline $\mathrm{CPI}$ & 0.190162 & -0.093070 & -0.073100 & 0.074742 & 0.411652 & 1.000000 & & & \\
\hline$C B$ & 0.218331 & -0.026970 & -0.087602 & 0.063702 & -0.027039 & 0.207885 & 1.000000 & & \\
\hline PCG95 & 0.212832 & -0.006774 & -0.051270 & -0.069325 & -0.040217 & 0.047507 & 0.255752 & 1.000000 & \\
\hline EF & 0.144478 & -0.068298 & -0.151016 & -0.072068 & -0.047332 & 0.076305 & -0.077795 & 0.301031 & 1.000000 \\
\hline
\end{tabular}

In Table 2, below, we present the best estimation results. We used pooled least squares and, to take care of the problem of autocorrelation of first degree, we added AR (1) term to our model:

Table 2

Estimation results

\begin{tabular}{|l|c|c|c|}
\hline Variable & Coefficient & T-Statistic & Probability \\
\hline $\log (\mathrm{PCG} 95)$ & $0.50^{*}$ & 2.02 & 0.04 \\
\hline $\log (\mathrm{GDP})$ & $0.31^{*}$ & 4.19 & 0.00 \\
\hline $\log (\mathrm{CB})$ & -0.09 & -0.98 & 0.33 \\
\hline $\log (\mathrm{ExR})$ & $-0.13^{*}$ & -3.01 & 0.00 \\
\hline $\log (\mathrm{PF})$ & 0.02 & 0.33 & 0.74 \\
\hline $\log (\mathrm{EF})$ & $0.36^{* *}$ & 1.72 & 0.09 \\
\hline AR(1) & $0.95^{*}$ & 67.54 & 0.00 \\
\hline & & & \\
\hline R Squared & 0.96 & & \\
\hline Adj R squared & 0.96 & & \\
\hline Durbin-Watson Stat & 1.81 & & \\
\hline Total Observations & 248 & & \\
\hline
\end{tabular}

* Significant at 5 per cent level.

** Significant at 10 per cent level.

A number of important results were obtained.

First, market size, measured as per capita GDP (2000 US\$), in the base year 1995 leads to higher inward FDI. The coefficient is significant at 5 per cent level.

Second, higher growth of real GDP (2000 US\$) leads to higher inward FDI. The coefficient is significant at the 5 per cent level. The findings indicate that the initial size of the market is more important than the rate of GDP growth.

Third, higher ExR leads to lower inward FDI. In other words, depreciation of the local currency (host country) or appreciation of US\$ (as measure of home country currency) leads to lower inward FDI. As indicated above, high collinearity between ExR and CPI led us 
to estimate only one of the two independent variables at a time. Collinearity between ExR and CPI is to be expected, as ceterisparibus higher inflation rate should lead to the depreciation of its currency. When CPI was used in place of ExR, a higher percentage growth in CPI or higher inflation leads to a lower inward FDI $^{10}$. The coefficients for both ExR and CPI were significant at 5 per cent level.

Fourth, lower exports to imports ratio or lower current account surplus, or higher current account deficit lead to greater inward FDI. However, this coefficient was not significant at the 5 per cent or 10 per cent level.

Fifth, higher economic freedom results in higher inward FDI. This coefficient is significant at the 10 per cent level. The coefficient value of 0.36 with respect to economic freedom (EF) as compared to 0.02 that was obtained for political freedom (PF) indicates that economic freedom is relatively more important than political freedom, as far as inward FDI is concerned.

Six, lower political risk, or political freedom value, correlate with higher inward FDI. However, this coefficient is not significant at either the 5 per cent or the 10 per cent level.

The main interest in this statistical analysis is to demonstrate the importance of institutional factors in explaining FDI flows to DCs. The results clearly support the view that EF, PRISK, and PF had explanatory power. However, the dominance of macroeconomic factors as drivers of FDI, i.e. GDP, PCG95, ExR, CPI, and CB, was confirmed.

In terms of hypotheses testing, the findings confirmed the validity of seven out of nine hypotheses. The impact of institutional factors on FDI produced mixed results. Hypothesis 1 postulated that higher political risk or lower political freedom (as indicated by lower PRISK value) will have an inverse relationship to FDI inflows in DCs. This hypothesis proved to be true, as PRISK had a positive correlation to FDI, though our results were not statistically significant. In Hypothesis 1, a positive correlation between PRISK and FDI is not supported by the results. A possible explanation for the low significance of PRISK is that high risks are tolerated if ROI is also high; long-term strategic opportunities may overshadow short- term political risk exposure. The efficiency of mitigating risk management strategies to protect investment assets against government intervention and political instability, e.g. political risk insurance, international mediation contracts, IJVs with state-owned enterprises or local partners, may be efficient.

Hypothesis 2 was not tested, as OPRISK was omitted as an independent variable because of its high collinearity with PRISK. The positive significance of EF for FDI, as postulated in Hypothesis 3, shows that institutional change, on the macro political, bureaucratic and economic levels, points to the strengthening of the investment climate in DCs. This result thus emphasises that the wider institutional setting in DCs, brought about by the liberalisation of markets, will probably stimulate and accommodate FDI flows to DCs. These liberalisation processes may appear disorderly, because market imperfections and unconsolidated democracies remain a feature of the institutional setting of many DCs. However, EF strongly suggests that reform and institutional changes are ongoing processes that are, on balance, beneficial for the investment climate in DCs.

The results show that all macroeconomic factors proved to be significant and positive for FDI flows to the cross-country panel in the sample. Among all the independent variables, both institutional and macroeconomic, market size (as captured by PCG 95) and growth of GDP were the most consistently significant factors explaining FDI flows to DCs, thereby confirming Hypotheses 4 and 5. This is consistent with the findings of Tuman and Emmert (1999), Trevino, Daniels and Arbelaez (2002), and Trevino and Mixon (2004) that GDP is a significant and positive indicator of FDI flows to DCs. The growth of market size in many DCs in support of economies of scale for production strongly indicates that GDP will likely persist as the main driver of FDI flows to DCs. This also supports conventional wisdom that larger markets in the developing world - China, India, and Brazil - will offer more investment opportunities than do smaller markets.

The findings also support Hypothesis 6: Higher inflation rates in host countries will lead 
to lower levels of FDI inflows. This supports the argument that a high rate of inflation is a sign of internal economic instability and of a host government's inability to maintain effective monetary policy. From the MNEs' viewpoint, high inflation creates uncertainty regarding the net present value of a costly long-term investment and the value of earnings earmarked for repatriation. This result is in line with findings by Schneider and Frey (1985) and Trevino, Daniels and Arbelaez (2002), which showed that companies invested less in DCs with high inflation rates.

The results also support Hypothesis 7B: Our results showed that depreciation of the host country's currency leads to lower FDI inflow. This is consistent with our earlier result of high positive correlation between CPI and ExR, ceteris-paribus, higher inflation should lead to depreciation of the currency. These results are contrary to general theoretical expectations that depreciation of a host country's currency should lead to greater FDI, as it will cost foreigners less (in their own currency) to invest in a host country. It is entirely possible that higher inflation and depreciation are taken as signs of weakness of developing countries, and thus lead to lower FDI. This finding is consistent with previous studies related to the market disequilibrium in DCs (Grosse \& Trevino, 1996; Klein \& Rosengren, 1994). It is also in line with location theories of FDI that weaker currencies in host countries lower the costs of investment factors like capital, taxes and operations (e.g. labour, facilities) (Dunning, 1988).

Finally, the findings also confirm Hypothesis 8: A deficit on the current account of the BOP of host countries will have a negative impact on FDI inflows to DCs. However, the correlations were not measured at a significant level.

Future research may deal with the issue of endogeneity. Borenszsten, DeGregorio and Lee (1998) noted that FDI and growth rates could arise from an endogenous determinant of $\mathrm{FDI}^{11}$. Gunaydin and Tatuglu (2005) found strong evidence of bi-directional causality between FDI and economic growth in Turkey. They caution against generalisation and recommend, quite appropriately, that this hypothesis should be tested in a larger panel of emerging markets.
Future research may also deal with improved measurement of institutional variables, which are often based on qualitative or subjective indicators. For example, commercial political and operational risk assessments differ in their prowess to predict risk (Howell \& Xie, 1996). Others have pointed to the limitations of the qualitative or subjected indices of political risk assessment (Cosset \& Roy, 1991; Oetzel, Bettis \& Zenner, 2001). Managers should develop an integrative risk management strategy based upon various sources, whether outsourced or developed in-house. Risk assessment should involve managers from both the parent and subsidiary levels of the firm.

A further area of future research may be a comparative study of institutional and macroeconomic drivers of inward FDI in various groupings of countries, i.e. OECD, emerging markets, or developing countries. The contention is that variation in institutional sophistication and macroeconomic vibrancy may result in different levels of inward FDI across such country cohorts.

\section{9}

\section{Managerial and economic implications}

In this study, cross-country differences in institutional and macroeconomic environments were used to explain FDI inflows to DCs. On the general level, this study explains some "pull" factors that attract MNEs to invest in DCs. The economies of DCs are inextricably linked to FDI, while the internationalisation of firms has led to an increase in FDI in new markets of the developing world. These markets are crucial to MNEs in enhancing profitability and remaining competitive in a globalised economy.

It is well established that MNEs must conform to the institutional environment in the host country in order to remain competitive. Accordingly, firms should understand and monitor the level of macroeconomic and institutional reform that has taken place in proposed host countries in the developing world. Trevino and Mixon (2004) propose that managers of MNEs could develop and/or apply separate 
statistical indices comprising macroeconomic and institutional information for proposed host countries. They advise managers to take particular care to examine host country institutional environments (reform) and recommend the use of a longitudinal data base (indices for individual countries) for formulating FDI strategies.

The firm or industry, e.g. trade associations, as political actors will be challenged to find the suitable hybrid strategy (proactive lobbying and/ or passive participation) to advance institutional change that promotes the attractiveness of the investment environment in DCs. Such political strategies should focus not only on the political system or government of host countries, but also on other actors, e.g. home governments, international organisations (WTO) and NGOs, which may provide impetus for market and political liberalisation in DCs.

\section{0}

\section{Conclusion}

The findings provide some support for the logic based upon New Institutional Economics (NIE). They also imply that country-level efforts to attract FDI will favour governments in DCs with strong institutions, i.e. sound monetary policy, liberalisation of institutions that reduce uncertainty and FDI-related transaction costs for foreign investors, as well as a level playing field for both foreign and domestic investors. The value of adding qualitative institutional variables to quantitative macro-economic variables related to the FDI environment has been demonstrated in this study. With the improvement in measurement of institutional variables, the ability to explain and to understand drivers of FDI has improved significantly.

\section{Endnotes}

1 NIE, according to Harris, Hunter \& Lewis (1995), focuses on the intersection of institutional environments and firms resulting from market imperfections. Institutions provide the rules-ofthe-game that structure societal interactions and, according to North (1990), a firm's actions are bound by such rules. It appears that NIE falls within the ambit of internationalisation theory.
2 Butler \& Joaquin's assessment is that PR in host governments is too state-centric and underestimates the risks posed to international business by interest groups such as labour unions, terrorist organisations, trade associations of host country-based competitors, and NGOs.

3 The authors define opacity as "the degree to which there is a lack of clear, accurate, easily discernible and widely accepted practices governing the relationship among businesses, investors and governments" (p. 40). The overall rating is used to assign an interest-rate premium or discount derived from doing business in a given country as compared to doing business in the USA.

4 E.g., The African Growth Opportunities Act (AGOA) provides tariff-free access for African textile and agricultural products to US markets for those African countries that meet acceptable standards of democratic governance. See http:// www.agoa.gov/agoa_legislation/agoa_legislation. html.

5 China, as a host country in the developing world, illustrates this trend. With a fast growing economy and the largest population in the world, China received a record $\$ 57$ bn of FDI in 2003, despite the slump in world FDI flows in 2001-2003.

6 Hyperinflation may be defined as cumulative inflation in excess of 100 per cent over a three year period (Eiteman, Stonehill \& Moffet, 2001).

7 A country's BOP account records both its payments to and its receipts from other countries. A government is normally concerned when it is running a deficit on the current account of the BOP. The current account tracks the exports and imports of goods and services. A current account deficit arises when a country is importing more goods and services than it is exporting.

8 Inward FDI stock has been used in place of inward FDI flow to take care of problems caused by some negative inward FDI flow. Thus change in inward FDI stock is used as proxy for FDI inflow. The same reasoning applies to use of GDP and CPI, as some numbers pertaining to their respective growth rates were negative. To take care of negative numbers associated with current account balance (exports of goods and services - imports of goods and services), we have taken the ratio of exports of goods and services to imports of goods and services as a proxy for current account balance (CB).

9 See Appendix 1 for a more detailed description of variables.

10 These results using CPI in place of ExR are available on request. 
11 "It should be noted that cross-country regressions presented here may be subject to endogeneity problems. The correlation between FDI and growth rate could arise from an endogenous determination of FDI, that is, FDI itself may be influenced by innovations in the stochastic process of governing growth rates. For instance, any omitted factors that raise the rate of return on capital will also increase both growth rate and the inflow of foreign direct investment simultaneously. In these circumstances there would exist a correlation between FDI and the country - specific error term, which would bias the estimated coefficients. Although, in principle, the endogeneity problem can be avoided by applying instrumental variable techniques, the fundamental problem is that there are no ideal instruments available (Borenszsten, DeGregorio \& Lee, 1998).

\section{References}

1 AHMED, R. (2003) "Globalization-democracy nexus: Empirical evidence from South Asia”, BIISS Journal, 24(4): 511-528.

2 AJAMI, R.A. \& BARNIV, R. (1984) "Utilizing economic indicators in explaining foreign direct investment in the US", Management International Review, 24(4): 16-26.

3 ALBUQUERQUE, R. (2000) "The composition of international capital flows: Risk sharing through foreign direct investment", Working Paper FR0008, Brandley Policy Research Center:University of Rochester: Rochester, NY.

4 ALIBAR, R.Z. (1970) "A theory of foreign direct investment", in The International Corporation, Kindleberger, C.P. (ed.) MIT Press: Cambridge, Mass.

5 ASIEDU, E. (2004) "Reform and foreign direct investment in Africa: Absolute progress but relative decline", Development Policy Review, 22(1): 41-60.

6 ASIEDU, E. \& LIEN, D. (2004) "Capital controls and foreign direct investment", World Development, 32(3): 479-501.

7 AYKUT, D. \& RATHA, D. (2004) "South-south FDI flows: How big are they?", Transnational Corporations, 13(1): 149-176.

8 BAILEY, W. \& CHUNG, Y.P. (1995) "Exchange rate fluctuations, political risk, and stock returns: Some evidence from an emerging market", Journal of Financial \& Quantitative Analysis, 30(4): 541-561.

9 BALASUBRAMANYAM, V.N. \& MAHAMBARE, V. (2002) Foreign Direct Investment in India, United Nations University Publications.
10 BASU, P., CHAKRABORTY, C. \& REAGLE, D. (2003) "Liberalization, fdi, and growth in developing countries: a panel cointegration approach", Economic Inquiry, 41(3): 510-516.

11 BITZENIS, A. (2004) "Explanatory variables for low western investment interest in Bulgaria", Eastern European Economics, 42(6): 5-16.

12 BLACKMAN, A. \& WU, X. (1999) "Foreign direct investment in China's power sector: Trends, benefits and barriers", Energy Policy, 27(12): 695-703.

13 BORENSZSTEN, J.; DEGREGORIO, J. \& LEE, J-W. (1998), "How does foreign direct investment affect economic growth?," Journal of International Economics, 45: 115-135.

14 BURTON, F.N. \& HISASHI, I.A. (1987) “A country risk appraisal model for foreign asset appropriation in DCs", Applied Economics, 19(8): 1009-1048.

15 BUTLER, K.C. \& JOAQUIN, D.C. (1998) “A note on political risk and the required return on foreign direct investment", Journal of International Business Studies, 29(3): 599-608.

16 CARSTENSEN, K. \& TOUBAL, F. (2004) "Foreign direct investment in Central and Eastern European countries: A dynamic panel analysis", Journal of Comparative Economics, 32(1): 3-19.

17 CAVUSGIL, S.T.; KNIGHT, A. \& RIESENBERGER, J.R. (2008) International Business: Strategy, Management, and the New Realities, Pearson Prentice Hall, UpperSaddle River, New Jersey.

18 CHOWDHURY, A. \& MAVROTAS, G. (2003) "FDI \& growth: What causes what?", WIDER Conference on "Sharing Global Prosperity", WIDER, Helsinki, 6-7 September: 1-18.

19 CORTELL, A.P. \& PETERSON, S. (2002) Altered States: International Relations, Domestic Politics, and Institutional Change, Lexington Books: Lanham, MD.

20 COSSET, J.C. \& ROY, J. (1991) “The determinants of country risk ratings", Journal of International Business Studies, 22(1): 135-142.

21 DEWENTER, K.L. (1995) "Do exchange rate changes drive foreign direct investment?", Journal of Business, 68(3): 405-431.

22 DUNNING, J.H. (1988) Explaining International Production, Unwin Hyman: London.

23 EITEMAN, D.K.; STONEHILL, A.I. \& MOFFETT, M.H. (2001) Multinational Business Finance, $\left(9^{\text {th }}\right.$ ed.) Addison Wesley: Boston.

24 ERDAL, F. \& TATOGLU, E. (2002) "Location determinants of foreign direct investment in an emerging market economy: Evidence from Turkey", Multinational Business Review, 10(1): 21-27. 
25 ERRAMILLI, M.K. \& RAO, C.P. (1993) "Service firms' international entry-mode choice: A modified transaction-cost analysis approach", Journal of Marketing, 57, 3): 19-38.

26 ESUOLA, O.A. \& ADELEKE, S.O. (2006) "Impact of exchange rate on foreign private investment in Nigeria", The Business Review, 5(2).

27 FARIA, A. AND MAURO, P. (2004) Institutions and the External Capital Structure of Countries, IMF working paper WP/04/236, Washington: International Monetary Fund.

28 FATEHI, K. \& SAFIZADEH, M.H. (1994) "The effects of sociopolitical instability on the flow of different types of foreign direct investment", Journal of Business Research, 31: 65-73.

29 FROOT, K.A. \& STEIN, J.C. (1991) "Exchange rates and foreign direct investment: An imperfect capital markets approach", Quarterly Journal of Economics, 106(November): 1191-1217.

30 GROSSE, R. \& TREVINO, L.J. (2005) “New institutional economics and FDI location in Central and Eastern Europe", Management International Review, 45(2): 123-145.

31 GROSSE, R. \& TREVINO, L.J. (1996) "Foreign direct investment in the United States: An analysis of country of origin", Journal of International Business Studies, 27(1): 139-155.

32 GYAPONG, A.O. \& KARIKARI, S.A. (1999)

"Direct foreign investment strategies and economic performance in Ghana and Ivory Coast", Journal of Economic Development, 24(1): 133-146.

33 HARRIS, J.; HUNTER, J. \& LEWIS, C.M. (1995) The New Institutional Economics and Third World Development, Routledge: London.

34 HEINRICH, J. \& KONAN, D. (2001) "Prospects for FDI in AFTA, ASEAN", Economic Bulletin, 18(2): 141-160.

35 HILL, C.W.L. (2006) Global Business Today ( $4^{\text {th }}$ ed.) McGraw-Hill Irwin: Boston.

36 HOSKISSON, R.; EDEN, L.; LAU, C.M. \& WRIGHT, M. (2000) "Strategy in emerging economies", Academy of Management Journal, 43(3): 249-267.

37 HOWELL, L.D. \& CHADDICK, B. (1994) "Models of political risk for foreign investment and trade: An assessment of three approaches," The Columbia Journal of World Business, 29(3): 7091.

38 HOWELL, L.D. \& XIE, D. (1996) "Asia at risk: The impact of methodology in forecasting", Management Decision, 34(9): 6-17.

39 HSIAO, C \& SHEN, Y (2003) "Foreign Direct investment and Economic Growth: The importance of institutions and urbanization",
Economic Development and Cultural Change, 51(4): 883-896.

40 HUNTINGTON, S.P. (1971) "The change to change: Modernization, development, and politics", Comparative Politics, 3(3): 283-322.

41 JAIN, A.K. (2001) “Corruption: a review”, Journal of Economic Surveys, 50(1): 71-121.

42 JENSEN, N.M. (2003) "Democratic governance and multinational corporations: Political regimes and inflows of foreign direct investment", International Organization, 57(3): 587-611.

43 KELLER, G. \& WARRACK, B. (2000) Statistics for Management and Economics, Duxbury Thomason Learning: Pacific Grove, CA.

44 KIM, Z.K. (2004) "The allocation and motivation of Japanese and US foreign direct investment in an economically integrated area: The case of the European Union”, SAM Advanced Management Journal, 69(2): 47-58.

45 KEELER, J.T.S. (1993) "Opening the window for reform: Mandates, crises and extraordinary policymaking”, Comparative Political Studies, 25(4): 433-486.

46 KENNEDY, R.E. \& SANDLER, A. (1997) "Transition to a market economy: the components of reform", (case 9-797-080, Mimeo), Harvard Business School.

47 KLEIN, M. \& ROSENGREN, E. (1994) “The real exchange rate and foreign direct investment in the United States: Relative wealth versus relative wage effects", Journal of International Economics, 36(3/4): 373-389.

48 KNACK, S. \& KEEFER, P. (1995) "Institutions and economic performance: Cross-country tests using alternative institutional measures", Economics and Politics, 7(3): 207-227.

49 KNICKERBOCKER, F.T. (1973) Oligopolistic Reaction and Multinational Enterprise, Harvard Business School Press: Boston.

50 KOBRIN, S.J. (2005) "The determinants of liberalization of FDI policy in developing countries: A cross-sectional analysis 1992-2001”, Transnational Corporations, 14(1): 67-104.

51 - (1976) "The environmental determinants of foreign direct manufacturing investment: An ex post empirical analysis", Journal of International Business Studies, 7(2): 29-42.

52 KURTZMAN, J., YAGO, G. \& PHUMIWASANA, T. (2004) "The global costs of opacity", MIT Sloan Management Review, 46(1): 38-44.

53 KRUGMAN, P.R. \& OBSTFIELD, M. (1994) International Economics: Trade and Policy, Harper Collins: New York. 
54 LI, Q. \& RESNICK, A. (2003) "Reversal of fortunes: Democratic institutions and foreign direct inflows to developing countries", International Organization, 57, 1): 175-192.

55 LIPSEY, R.E. (2002) "Home and host country effects on FDI", working paper ( 9293, October), (National Bureau of Economic Research, Cambridge, MA).

56 MAURO, P. (1995) "Corruption and Growth," Quarterly Journal of Economics, 110(3): 681-712.

57 MEON, P-G. (2004) "Does the quality of institutions limit the MENA's integration in the world economy", World Economy, 27(9): 14751488.

58 MERLEVEDE, B. (2000) "Growth in transition economies: A review of the literature", working paper, University of Antwerp, Department of Economics, July.

59 MIKLOS, S. (1995) "Experiences with foreign direct investment in Hungary", Russian and Eastern European Finance and Trade, 31(3): 6-41.

60 NIGH, D. (1985) "The effects of political events on United States direct foreign investment", Journal of International Business Studies, 16(1): 1-17.

61 NORDHAUS, W. (1975) "The political business cycle", Review of Economic Studies, (42): 169-190.

62 NORTH, D. (1990) Institutions, Institutional Change and Economic Performance, Cambridge University Press: Cambridge.

63 OETZEL, J.M., BETTIS, R.A. \& ZENNER, M. (2001) "Country risk measures: How risky are they?”, Journal of World Business, 36(2): 128-145.

64 PAN, Y. (2003) "Inflow of foreign direct investment to China: the impact of country-specific factors", Journal of Business Research, 56(10): 829833.

65 - 1996, "Influences on foreign equity ownership level in joint ventures in China," Journal of International Business Studies, 27(1): 1-26.

66 PAN, Y. \& LI, X. (2000) "Joint venture formation strategies of very large multi-national firms", Journal of International Business Studies, 31(1): 179-189.

67 PEROTTI, E. \& VAN OIJEN, P. (2001)

"Privatization, political risk and stock market development in emerging economies", Journal of International Money and Finance, 20(1): 43-69.

68 RAM, R. \& ZANG, K.H. (2002) "Foreign direct investment and economic growth", Economic Development and Cultural Change, 51: 205-225.

69 RAZIN, A. (2003) "FDI flows and domestic investment: Overview," CESifo Economic Studies, 49(3): 415-428.
70 ROOT, F.R. (1972) “Analyzing political risks in international business", in The Multinational Enterprise in Transition, Kapoor, A. \& Grub, P.D. (eds.) Darwin Press: Princeton, NJ: 345-365.

71 RUMELT, R.P.; SCHENDEL, D.E. \& TEECE, D.J. (1991) "Strategic management and economics", Strategic Management Journal, 12 (Special Issue): 5-29.

72 SADER, F. (1993) "Privatization and foreign investment in the developing world 1988-92", World Bank Policy Research Working Paper, Washington, D.C.

73 SAGGI, K. (2002) “Trade, foreign direct investment and international technology transfer", World Bank Research Observer, 17: 191-235.

74 SCHAMIS, H.E.\& WAY, C.R. (2003) "Political cycles and exchange-rate-based stabilization", World Politics, 56(1): 43-78.

75 SCHNEIDER, F. \& FREY, B.S. (1985)

"Economic and political determinants of foreign direct investment", World Development, 13(2): 161175.

76 SCHOLLHAMMER, H. \& NIGH, D. (1984) "The effects of political events on fdi by German multinational corporations", Management International Review, 24(1): 18-40.

77 SHAN, J.; GANG, G. \& SUN, F. (1997) “The FDI-led growth hypothesis: Further econometric evidence from China", Economic Division Working Papers, 2, The Australian National University: 120.

78 SHAN, J. \& TIAN, G.G. (1998) “Causality between exports and economic growth: The empirical evidence from Shanghai", Australian Economic Papers: 195-202.

79 SMITH-HILLMAN, A.V. \& OMAR, M. (2005) "FDI, international business and regulation: The behaviour of UK multi-national corporations", European Business Review, 17(1): 69-82.

80 TAHIR, R. \& LARIMO, J. (2004) “Understanding the location strategies of European firms in Asia countries", Journal of the American Academy of Business, 5(1\&2): 102-127.

81 TOMOHARE, A. (2004) "Globalization for development? Inward FDI and the size of the market," Southern Business Review, 30(1): 5-16.

82 TREVINO, L.J. (1999) "Market reform and foreign direct investment in Central and Eastern Europe: A comparative assessment", In Proceedings of Decision Sciences Institute, Despotis, D.K. \& Zopounidis, C. (eds.) New Technologies Publications: Athens.

83 TREVINO, L.J., DANIELS, J.D. \& ARBELAEZ, H. (2002) "Market reform and FDI in Latin 
America: An empirical investigation", Transnational Corporations, 11(1): 29-48.

84 TREVINO, L.J. \& MIXON, F.J. (2004) “Strategic factors affecting fdi decisions by multi-national enterprises in Latin America", Journal of World Business, 39(3): 233-243.

85 TUFTE, E. (1978) Political Control of the Economy, Princeton University Press: Princeton, NJ.

86 TUMAN, J.P. \& EMMERT, C.F. (1999)

"Explaining Japanese foreign direct investment in Latin America (1979-1992”, Social Science Quarterly, 80(3): 539-555.

87 UNITED NATIONS (2006) World Investment Report 2006, UN: New York \& Geneva.

88 - (2003) World Investment Report 2003, UN: New York \& Geneva.

89 - (2002) World Investment Report 2002, UNCTAD: New York \& Geneva.

90 - (2000) World Investment Report 2000, UN: New York \& Geneva.

91 - (1999) Foreign direct investment in Africa: performance and potential, UNCTAD: Geneva.

92 — (1998) World Investment Report 1998, UNCTAD: Geneva.

93 VERNON, R. (1966) "International investments and international trade in the product life cycle", Quarterly Journal of Economics, 80: 190-207.

94 VOYER, P.A. \& BEAMISH, P.W. (2004) "The effect of corruption on Japanese foreign direct investment”, Journal of Business Ethics, 50(3): 211226.
95 WEI, S-J. (2000) "Local corruption and global capital flows", Brookings Paperson Economic Activity, 2: 303-354.

96 WHEELER, D., \& MODY, A. (1993) "International investment location decisions: the case of U.S. firms", Journal of International Economics, 33: 57-76.

97 WILD, J.J.; WILD, K.L. \& HAN, J.C.Y. (2006) International Business: the Challenges of Globalization, (3 ${ }^{\text {rd }}$ ed.) Prentice-Hall: Upper Saddle River, NJ.

98 ZHANG, K.H. (2001) "Does foreign direct investment promote economic growth? Evidence from East Asia and Latin America", Contemporary Economic Policy, 19(2): 175-185.

99 ZHANG, K.H. (1995) "International trade and foreign investment: Further evidence from China", Asian Economic Journal, 23: 23-56.

100 ZHANG, K.H. (1999) "How does FDI interact with economic growth in a large developing country? The case of China", Economic Systems, 23(4): 291-303.

101 ZHANG, K.H. (2001) "How does foreign direct investment affect economic growth in China?", Economics of Transition, 9(3): 679-693.

102 ZHAO, H. (2003) "Country factor differentials as determinants of FDI flows to China", Thunderbird International Business Review, 45(2): 149-169. 


\section{Appendix 1}

A descriptive list of variables

\begin{tabular}{|c|c|}
\hline Variables & Source \\
\hline $\begin{array}{l}\text { I. Dependent variable } \\
\text { Foreign Direct } \\
\text { Investment(FDI) }\end{array}$ & $\begin{array}{l}\text { The total accumulated annual (from all source countries) value of FDI } \\
\text { investment to individual DCs for all industries expressed in US dollars. } \\
\text { Data: United Nations Conference on Trade \& Development (UNCTAD), } \\
\text { World Investment Report 2006, Statistical Annex CD }\end{array}$ \\
\hline $\begin{array}{l}\text { II. Independent variables } \\
\text { Political Risk(PRISK) }\end{array}$ & $\begin{array}{l}\text { The Political Risk Index is compiled by Business Environment Risk } \\
\text { Intelligence SA. The Index focuses wholly on socio-political conditions in } \\
\text { a country by creating a multi-component system with flexibility to weigh } \\
\text { key factors, and by utilising a permanent panel of experts with diplomatic } \\
\text { careers and training in political science. On a scale of } 0-100 \text {, the higher } \\
\text { the aggregate score, the lower the country's political risk; or the lower the } \\
\text { aggregate score, the higher a country's political risk. }\end{array}$ \\
\hline Operations Risk(OPRISK) & $\begin{array}{l}\text { The Operations Risk Index is compiled by Business Environment Risk } \\
\text { Intelligence SA. The objective of OPRISK is to gauge the operations climate } \\
\text { for foreign businesses. Two broad variables are measured: the degree to } \\
\text { which nationals are given preferential treatment; and the general quality of } \\
\text { the business climate, including bureaucratic and policy continuity. A panel } \\
\text { of experts rate operations conditions annually on a scale ranging from 0- } \\
\text { 100. Thus, the lower the aggregate score, the higher the operations risk; or } \\
\text { the higher the aggregate score, the lower the operations risk. }\end{array}$ \\
\hline Political Freedom (PF) & $\begin{array}{l}\text { Political Freedom: The Freedom in the World Index has been compiled by } \\
\text { Freedom House since 1972. Ratings are based on a checklist of } 10 \text { political } \\
\text { rights questions grouped into three sub-categories (electoral process, } \\
\text { political pluralism \& participation, functioning of government, parties or } \\
\text { groupings) }\end{array}$ \\
\hline Economic Freedom (EF) & $\begin{array}{l}\text { Economic Freedom: The Index of Economic Freedom is compiled by the } \\
\text { Wall Street Journal \& the Heritage Foundation. The Index is based on a } \\
\text { set of objective economic criteria that have been used since } 1995 \text { to rank } \\
\text { countries on an annual basis. The Index is based on a theoretical analysis of } \\
\text { the factors that most influence the institutional setting of economic growth. } \\
\text { There are } 50 \text { variables grouped into } 10 \text { categories of freedom: business, } \\
\text { trade, fiscal, government size, monetary, investment, financial, property, } \\
\text { labour and freedom from corruption. http://www.heritage.org/index }\end{array}$ \\
\hline Currency Valuation(ExR) & $\begin{array}{l}\text { Exchange rate of national currency vis-à-vis US dollars Data: World } \\
\text { Development Indicators } 2006 \text { (World Bank) }\end{array}$ \\
\hline $\begin{array}{l}\text { Current Account Balance } \\
\qquad \text { (CB) }\end{array}$ & $\begin{array}{l}\text { Export of goods (current US\$/Imports of goods and services (current US\$) } \\
\text { UN World Development Indicators (2006) }\end{array}$ \\
\hline Inflation(INFLATE) & $\begin{array}{l}\text { Annual \% change in inflation rate, measured by CPI Data: World } \\
\text { Development Indicators } 2006 \text { (World Bank) }\end{array}$ \\
\hline Market Size(GDP) & $\begin{array}{l}\text { Market size as measured by } 1995 \text { GDP (2000 US\$) or } 1995 \text { per capita GDP } \\
\text { (2000 US\$). World Development Indicators 2006. (World Bank) }\end{array}$ \\
\hline Economic Growth Rate & Annual GDP. Data: World Development Indicators 2006. (World Bank) \\
\hline
\end{tabular}



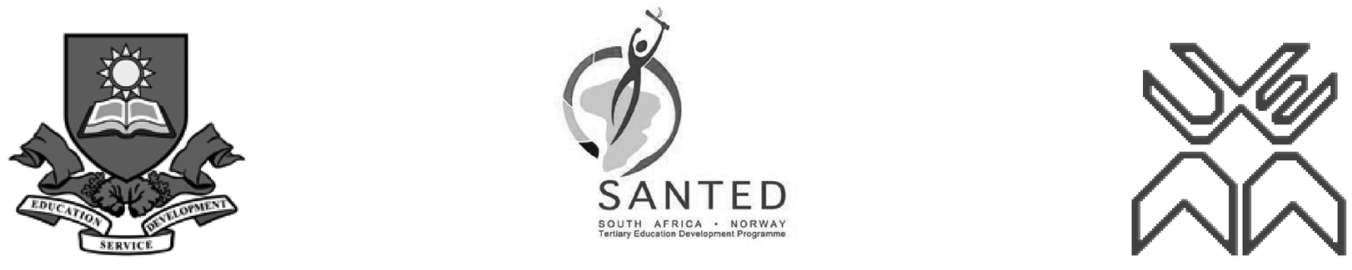

The Universities of Botswana, Namibia, the Witwatersrand and Eduardo Mondlane University are pleased to announce a Call for Papers for a conference on "Economic Aspects of Southern African Regional Integration" to be hosted by the University of Botswana in Gaborone, from 5 to 6 March 2009.

Suggested themes include:

- Economics issues at regional level

- International Trade

- Regional Integration

- Poverty \& Poverty Policy

- Migration ( e.g. Xenophobia)

- Energy Policy

- Trade Blocks (e.g. SAICU)

- Food Security

- Institutional Capacity for Management of Regional Issues

- EPAs

- Future of Regional Integration

- Evaluation of SADC Programmes \& Targets

Limited funding, as part of the SANTED project, is available to cover conference and other research related costs for selected papers. A special issue of a Southern African journal, that includes the best papers presented at the conference, will also be published.

Authors are invited to submit a one page abstract to the project coordinators at their university:

Dr Imogen Mogotsi (mogotsii@mopipi.ub.bw) - University of Botswana;

Dr Omu Kakujaha-Matundu (okakujaha@unam.na) - University of Namibia;

Prof. M. Lopez (marflope@ zebra.um.mz) - Eduardo Mondlane University; or

Dr Neil Rankin (neil.rankin@wits.ac.za) - University of the Witwatersrand, and for those at other universities.

The closing date for abstracts is Friday $31^{\text {st }}$ October 2008. Final papers are to be submitted by the $15^{\text {th }}$ February 2009.
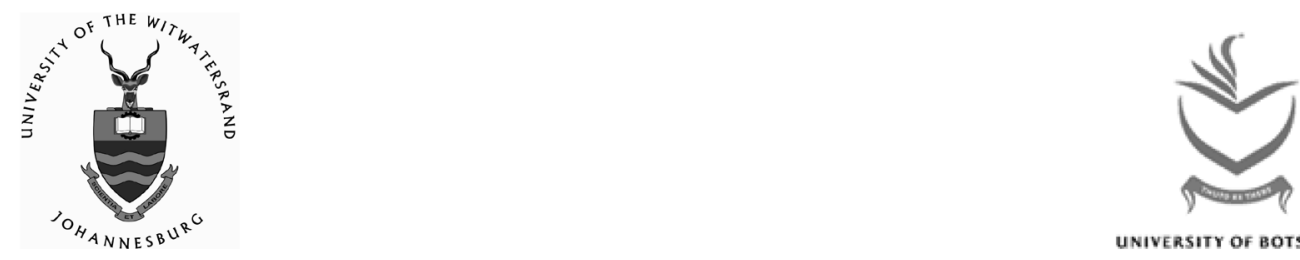

UNIVERSITY OF BOTSWANA 